Ђорђе Божовић

Универзитет у Београду

Филолошки факултет $811.18^{\prime} 373$

https://doi.org/10.18485/melissa.2017.16.1.ch6

\title{
ПУТЕВИ РЕЧИ У АЛБАНСКОМ ЈЕЗИКУ
}

\begin{abstract}
Сажетак
У раду се представљају различити слојеви вокабулара и износи се периодизација лексичких позајмљеница у албанском језику, с посебним освртом на најновију лексику (интернационализме) и лакоћу њихове интеграције у језички систем, која одражава специфичан континуитет језичких и културних контаката у овој говорној заједници. Уједно се тврди како лексичка адаптабилност представља и ареалну особину балканскога језичког савеза.

Кључне речи: лексичке позајмљенице, периодизација, међујезички контакти, слојеви вокабулара, адаптабилност лексикона, албански језик, балкански језички савез.
\end{abstract}

\section{1. Увод}

Албански језик је готово јединствен међу језицима Европе и Балкана по степену међујезичких контаката који су у њему посведочени од најранијег доба до савременог стања и различитим слојевима лексичких позајмљеница које су у њега интегрисане. С тачке гледишта традиционалне европске граматике и њених националних филологија, о таквим се међујезичким контактима обично размишља као о местима дисконтинуитета у језичкој историји. Бројни европски језици имају речнике страних речи, што сведочи о томе да се овај слој вокабулара перципира као другачији и да на известан начин није у потпуности интегрисан у језички систем, многима (исландски, мађарски, словеначки и др.) нису непознати ни такви механизми попут калкирања, који у њиховим лексичким системима и дериватологији представљају живље механизме настанка нових 
речи него позајмљивање, а у некима је (као у енглеском) чак и читав граматички и лексички систем тако организован да јасно разазнаје слој домаћих од позајмљених основа, на које се онда примењују и сасвим различите морфолошке операције (нпр. комбинују се с различитим афиксима или не подлежу истим морфонолошким правилима и ограничењима), често су и различитих семантичких или стилских вредности и сл. С друге стране, у албанском су све речи страног порекла тако добро интегрисане у језички систем да је најчешће тешко повући границу између њих и „домаћих“ речи, осим са аспекта научне етимологије, нити их сами изворни говорници тако перципирају и оне равноправно учествују у творби без обзира на порекло (могу се комбиновати стране основе са домаћим афиксима и обратно, све су продуктивне, не носе нарочиту стилску или семантичку обојеност). И не само што се албански језик одликује таквом лакоћом адаптације, па су „стране речи“ квалитативно нешто другачије у њему него што су то, рецимо, у енглеском чији је лексикон доследно предвојен на два лексичка слоја, него су оне и у квантитативном смислу посебан случај, будући да представљају преовлађујући део лексикона - сваки „речник страних речи“ би у случају албанскога практично био и скоро целокупан једнојезични речник албанскога, с изузетком неколико стотина наслеђених основа непосредно из прајезика (Demiraj 1997: 37 таквих налази укупно 572). Јер, то је обележје албанскога које се може пратити током читаве његове историје на Балкану - од најранијег супстрата заједничког с румунским и позајмљеница из грчкога и латинскога, преко каснијих слојева славизама и турцизама, млађих романизама, до најновијег слоја тзв. интернационализама (в. Demiraj 1989: 105-130). Сваки од тих слојева вокабулара био је тако адаптиран у језик да се касније са њим могло рачунати као и са наслеђеним речима, у сваком смислу осим етимолошки, а и ту постоје извесни проблеми (уп. Божовић 2015: 8-9).

Ако бисмо, дакле, лексикон посматрали из угла континуитета и дисконтинуитета језичке историје, албански би био својеврстан случај у коме је „дисконтинуитет“ заправо континуитет, тј. у коме се континуитет не огледа у чувању истих лексичких основа кроз време, већ у сталним међујезичким контактима и лексичком позајмљивању које заправо одсликава структуру овог језика, где је, дакле, на делу 
континуитет дисконтинуитета. Мада, наравно, књижевном албанском језику нису стране ни пуристичке тенденције, тај континуитет лексичке адаптабилности у њему се огледа и у најсавременије доба, где се такође јављају бројни тзв. интернационализми, о којима ће посебно бити речи ниже. У раду ћу, наиме, након веома кратког теоријског увода, најпре представити етимолошки различите слојеве албанског вокабулара, а затим намеравам повести дискусију о њима у контексту балканске миксоглотије. Моја теза је да је управо адаптабилност лексикона једна од особина балканскога језичког савеза, која се најбоље огледа у албанском језику као једном од средишњих језика овога савеза, али није непозната ни другим балканским језицима, укључујући ту и српскохрватски, те да управо она на терену српскохрватскога, поред других изоглоса, најбоље указује на северозападну границу балканскога ареала.

\section{2. О речима из угла балканске лингвистике}

Традиционална историјска граматика је донекле скептично посматрала феномен језичког контакта. Тежећи да у језику разабере оне најстарије елементе и „корене“ који га повезују са сродним језицима, будући усмерена на задатак реконструкције прајезика, она је помало подозриво гледала на производе међујезичких контаката, међу којима су пре свега лексичке позајмљенице, „плевећи“ их као стране елементе из језичког ткива и не посвећујући им потребну пажњу. У историјама балканских језика, међутим, језички контакт и међујезичко позајмљивање је било немогуће избећи - оно је већ у дефиницији самог појма балканизације - па су управо истраживачи балканских језика били први који су и системски приступили феномену позајмљивања као саставном делу историје језика - како истиче Фридман: „Balkan linguistics was the first modern approach to language that attempted to deal with the consequences of language contact as a normal phenomenon rather than as 'corruption'“ (Friedman 2011: 276).

Лексичко позајмљивање је најчешћа и најпроширенија последица међујезичког контакта. Нема језика без позајмљеница - изузев ако су читаво своје постојање провели изоловани од свих 
других језика, али такви још нису пронађени - управо стога што је међујезички контакт природна последица културолошког контакта и живота људи који језиком говоре и упућени су на друге људске заједнице. Начини на које језици примају елементе из других језика и на које их адаптирају у сопствени лексички, граматички и фонолошки систем представљају и главни предмет истраживања савремене контактне лингвистике, а често уједно осветљавају и нека питања теоријске лингвистике уопште (за преглед области, в. Matras 2009). Тако се, између осталог, постављају питања шта је све подложно позајмљивању и да ли постоје тзв. хијерархије позајмљивости - нпр. пуне (лексичке) речи пре него граматеме, самосталне (именице) пре него несамосталне речи, одређена семантичка поља пре него нека друга (рецимо, тзв. културне речи с једне спрам основног вокабулара с друге стране, као у дефиницији језичког савеза Трубецког) и сл.

У контексту језичких савеза какав је балкански, постојање заједничке лексике је утолико и мање изненађујуће. Ипак, теорија језичких савеза не само што није лексичко позајмљивање сматрала важном ареалном особином, већ му је доследно претпостављала заједничке граматичке особине. Тако се из гласовитих Копитаревих речи о балканским језицима као „једној језичкој форми, али са тројаком [i.е. албанском, балканороманском и словенском] језичком материјом“ (Kopitar 1829: 86) види да он сматра како ови језици деле заједничке граматичке особине, док је конкретна лексика - различита. И за потоње истраживаче ће, следећи Трубецког, заједничке структурне особине балканских језика бити далеко важније него лексичке, мада се каткада говори и о лексичким балканизмима (за преглед, в. Попов 1984; из референсне литературе уп. и Sandfeld 1930; Demiraj 1994; Асенова 2002; inter alia).

Старији компаратисти, код којих се прво и јавила свест о постојању међусобних веза између балканских језика, међутим, своја истраживања су доминантно усмеравали на речник (тако „отац балканологије“ Миклошич; уп. Miklosich 1861; 1867; 1870; 1871; 1884; и др.). Лексичко позајмљивање у различитим смеровима и у разна времена за њих је, како изгледа, недвосмислено било карактеристика балканских језика. При томе, није неопходно и да балкански језици нужно деле исти конкретан лексички фонд (али чак и то је 
случај с неким лексичким слојевима, попут заједничког супстрата или турцизама, који представљају заједнички суперстрат за све балканске језике), већ је сама тежња ка позајмљивању и адаптирању ненаслеђене лексике у сопствени вокабулар, као последица интензивних културних контаката, нешто што представља и структурну карактеристику ових језика и може се, стога, сматрати балканизмом.

И сам Шлајхер, на чију идеју о „искварености“ балканских језика заправо изнад реферира Фридман, изгледа да је управо имао у виду, макар неспретно формулисано и с лоше одабраном терминологијом, ареално јединство албанскога, балканословенских и балканороманских језика, које се огледа пре свега у њиховом паралелном удаљавању од одговарајућих прајезика (мада код албанског погрешно сматрајући за то грчки), како у домену граматике, тако свакако и лексички:

Es ist eine bemerkenswerthe Erscheinung, dass um die unteru Donau und weiter nach Südwesten sich eine Gruppe aneinandergränzender Sprachen zusammengefunden hat, die bei stammhafter Verschiedenheit nur darin übereinstimmen, dass sie die verdorbensten ihrer Familien sind. Diese missrathenen Söhne sind das Walachische in der romanischen, das Bulgarische in der slawischen und das Albanesische in der griechischen Familie. Das Verderbniss zeigt sich in der nördlichsten Sprache, der zuerst genannten, noch in einem geringeren Grade, mehr schon in der mittleren, dem Bulgarischen, und hat in der südlichen, der albanesischen einen ihre Herkunft fast völlig verdunkelnden Grad erreicht. (Schleicher 1850: 143)

Управо неоптерећен каснијим концептом балканског језичког савеза, Шлајхер је могао да примети „исквареност“ као заједничку општу карактеристику ових језика, а да она не мора нужно да буде исказана у свима истим језичким елементима. Другом речју, као што су и структурни балканизми заправо формално заједничке црте исказане у свим балканским језицима различитим конкретним лексичким садржајем (нпр. и Шлајхер ту у сва три језика уочава постојање постпозитивног члана уз именицу, али то није у свима иста конкретна морфема), тако и лексички дисконтинуитет балканских језика у односу на њихове старије фазе треба разумети као формално 
заједничку особину која се не мора и нужно исказати постојањем заједничких конкретних лексема у свима, али се исказује општом лексичком „исквареношћу“ како је тај појам, чини ми се, разумео Шлајхер, а то значи и високим степеном лексичког позајмљивања услед међујезичких контаката (уп. „[...] und hat in der südlichen, der albanesischen einen ihre Herkunft fast völlig verdunkelnden Grad erreicht", где је несумњиво реч и о лексици, тј. етимологији).

Сада ћемо ближе размотрити управо по Шлајхеру у том смислу „најискваренији“ од балканских језика - различите слојеве албанског вокабулара, са становишта модерне етимологије (за најскорије синтезе, в. Demiraj 1997 и Orel 1998; за преглед Божовић, op. cit.).

\section{3. Наслеђене лексичке основе}

Албански непосредно из индоевропског прајезика баштини тек неколико стотина лексичких основа. Међу њима су неки термини сродства попут atë 'отац' и motër 'сестра' (са семантичким помаком у односу на друге индоевропске језике) и уопште називи који се тичу човекових телесних функција, називи неких биљака и животиња ( $d r u$ 'дрво', ari 'медвед', ијk 'вук'), атмосферских појава (hёпё 'месец', diell 'сунце', natë 'ноћ') и уопште термини рељефа и околиша, затим многе радње (bie 'донети; пасти', djeg 'горети' итд.), те придеви, бројеви, заменице и уопште граматичке речи, које су у албанскоме претрпеле фонетске промене карактеристичне за овај језик.

Но, иако обилује позајмљеницама у свим, па и малопре поменутим семантичким пољима, важно је приметити да албански и у свим семантичким пољима има и речи из наслеђеног фонда, те да он функционише као продуктиван слој у језику (в. Demiraj 1989: 93-97).

\section{4. Албанско-румунски супстрат}

Посебан део наслеђеног лексичког фонда чини тзв. албанскорумунски супстрат, слој речи заједничких албанском и румунском језику, које нису романског порекла већ су и у једноме и у другоме 
прежици неког од старобалканских језика од кога се и развио албански. Такве су речи buzё (рум. buză) 'усна; ивица', gushë (рум. guşă) 'грло', mal (рум. mal) 'брдо' (у рум. 'обала'), moshë (рум. moş, moaşă) 'старост' (у рум. 'деда, баба'), votër (гег.) vatër (тоск.) (рум. vatră) 'огњиште' и др., а многе од њих ушле су и у све суседне словенске језике на Балкану и карпатском гребену, укључујући и српскохрватски (гуша, ватра итд.), када је овај раздвојио албански и румунски, ушавши и сместивши се између њих (за преглед с литературом, в. Çabej 1987a; Demiraj, op. cit.: 98-105; Ismajli 2012).

Већина ових лексичких основа сликовито одражава пасторални живот заједница на Балкану, њихову основну делатност - сточарство (тако и гег. katund 'село', сх. катун, или алб. bajgё од старијег balgё 'балега', рум. balegă), човека и патријархално друштвено уређење, као и његово непосредно планинско окружење. Иако су ранији лингвисти овом делу вокабулара давали велики значај (нпр. Вајганд и др.), покушавајући на основу њега да докажу афилијацију албанскога у кругу старобалканских језика, ваља приметити да су ово заправо врло живе општебалканске „лутајуће“ лексеме, које су лако касније ушле и у словенске језике и даље се шириле. Овај слој лексикона, према томе, пре сведочи о вековним узајамним везама између номадских карпатобалканских сточарских заједница, које су тек релативно скоро прекинуте модернизацијом, него о неком старом албанско-румунском (тј. трачком или дакомизијском) ексклузивитету.

\section{5. Антички грецизми}

Најстарије позајмљенице из неког суседног језика у праалбанском, иако сасвим ретке, могу се идентификовати као антички грецизми, тачније доризми, пошто показују фонетски облик северозападних грчких дијалеката (с дугим $\bar{a}$ наспрам атичке ете), оних у Епиру, са којима је албански најпре и могао да ступи у контакт, односно оних у грчким колонијама на обали (Драчу, Аполонији), које су основали дорски Коринћани. Такве су речи mokёn (гег.) mokёr (тоск.)

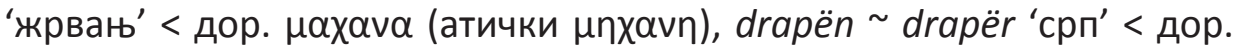




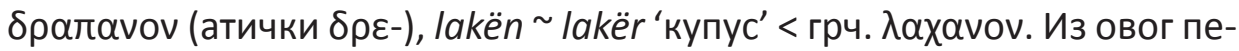
риода су и антички топоними на тлу Албаније (као Durrës < $\Delta$ uppaхıov, сх. Драч и др.), мада је њихова етимологија још мање јасна и постоје различита тумачења овога слоја албанског вокабулара, поново у вези са афилијацијом албанскога међу старобалканским језицима (в. Cimochowski 1960; Çabej 1987b; Demiraj, op. cit.: 174-181; Huld 1986; Лома 1991; Skok 1924). (За преглед ове лексике, в. и Demiraj, op. cit: 106-109.)

Од ових малобројних и не сасвим разјашњених старогрчких основа које спадају у праалбански период треба разликовати касније средњовековне и нововековне грецизме у албанскоме, релативно бројне у његовом јужном (тоскијском) дијалекту (в. ниже). Из овог прегледа изостављамо и стање у исељеничким арванитским говорима у Грчкој, где је јак билингвизам, из разумљивих разлога, у већој мери утицао и на структуру и лексику ових албанофоних говора, опет из неког каснијег времена.

\section{6. Три слоја латинизама}

Током касне антике, праалбански је језик претрпео интензивну романизацију, и то посебно на плану лексике. Што је још важније, период када су из вулгарног, у мањој мери и црквеног латинскога, у њега улазиле ове бројне позајмљенице представља уједно и формативни период албанског језика. Ово је, наиме, време како значајних фонетских, тако и структурних промена, и то не само у албанскоме, већ и у самоме латинскоме, па је, како примећује Орјол (Orel 2000: 23), утолико овај слој вокабулара интересантнији за албанску етимологију и историјску фонетику. Управо на основу тих измена, пре свега у вокализму, и латинизми у албанскоме се могу разврстати у три хронолошка слоја, сваки са унеколико различитим рефлексима у албанском, који сведоче о различитим фазама, а могуће и различитим зонама романизације (ibid.: 24 et seq.). Слично вреди и за рефлексе латинског консонантизма, где је посебно занимљива двојака адаптација лат. групе $c t>$ алб. jt (као у далматском и даље у роман- 
ским језицима на западу) и ft (аналогно рум. pt и уопште балканороманском рефлексу на истоку), што поново говори о албанскоме као прелазном идиому у коме се стичу различите изоглосе (ibid.: 116 et seq.; Çabej 1987c).

Позајмљенице из латинскога су, историјски очекивано, нарочито бројне у домену друштвених установа, укључујући ту и сакралне термине из периода христијанизације (kishë 'црква' < ecclesia, ungjill 'јеванђеље' < evangelium, meshë 'миса' < missa, ipeshkëv 'бискуп' < episcopus, engjëll 'анђео' < angelus, prift 'свештеник' < presbyter, djall 'ђаво' < diabolus, shpirt 'душа, дух' < spiritus, mёkat 'грех' < peccatum, mung murg 'монах' < monachus, shenjtë 'свети' < sanctus итд.; многе од њих су крајњег грчког порекла, одакле су ушле и у латински, а неке су пак и у албанскоме паралелено узајмљене из грчког, као peshkop 'епископ' < єльбколо - латински су називи чешћи на северу, где је јачи и утицај римокатоличке, док су грчки чешћи на југу, где је утицајнија грчкоправославна црква, па ту из средњовековног грчког долазе и kllogjër 'калуђер', manastir 'манастир' и сл.).

Овакви латинизми, који сведоче о утицају римске цивилизације, jecy и qytet 'град' < civitat- и други термини градитељства као mur 'зид' < murus, shtëрi 'кућа' < hospitium, затим термини друштвене организације shok 'друг' < socius, mik 'пријатељ' < amicus и armik 'непријатељ' < inimicus, fqinj 'сусед' < vicin(i)us, popull 'народ' < populus, термини рода и сродства као kunat 'зет' < cognatus, prind 'родитељ' < parent-, mashkull 'мушкарац' < masculus, femën femër 'жена' < femina и fёmiјё 'дете' < familia, титуле и занимања, тј. термини друштвене хијерархије, попут mbret 'краљ' < imperat-, mjek 'лекар' < medicus, bujk 'кмет' < bubulcus итд., апстрактуми pushtet 'власт, моћ' < potestat-, shëndet 'здравље' < sanitat-, затим kuvend 'говор, скупштина' < conventus и ligj 'закон' < lege-, kangë këngë 'песма' < canticum и përrallë 'бајка' < parabola, vepër 'дело' < opera, vërtetë 'истина' < veritat-, календарски називи као janar 'јануар', mars 'март', prill 'април', maj 'мај', gusht 'август' и називи дана e martë 'уторак' (тј. Марсов дан), е mërkurë 'среда' (тј. Меркуров д.), e shtunë 'субота'

(тј. Сатурнов д.), као и преведенице у лат. духу shtator 'септембар' (седми месец), tetor 'октобар' (осми м.), nëntor 'новембар' (девети 
м.), dhjetor 'децембар' (десети м.) и е hёпё 'понедељак' (тј. Месечев д.), e diel 'недеља' (Сунчев д.), ако нису већ постојали у старобалканском фолклору, одакле ваљда и e enjte 'четвртак' (према Орјолу, дан ватре, тј. калк према лат. Јупитеров д.) и e premte 'петак' (дан праалб. богиње љубави Пренде, тј. Венере), затим различити називи биљака и животиња, као ретё 'воће, стабло' < pomum, peshk 'риба' < piscis, ulli(n) 'маслина' < oliva, материјала као voj vaj 'уље' < oleum, ranë rënё 'песак' < arena, ar 'злато' < aurum и окружења као pyll 'шума' < palud- (са семантичким помаком, у лат. 'бара'), ishull 'острво' < insula, неки називи делова тела попут faqe 'образ' < facies и fytyrë 'лице' < factura, и многи, многи други (уп. и Demiraj, op. cit.: 109-115).

Као што се види из примера, лат. именице су се у албанскоме адаптирале према облику граматичке основе у зависним падежима. Осим њих, албански је зајмио и друге врсте речи, као и неке творбене морфеме.

\section{7. Славизми}

Након интензивних таласа романизације, уједно праћених и значајним гласовним и структурним променама, албански језик се консолидовао и формирао крајем антике у мање-више оном облику у коме ће се појавити и у својим првим споменицима. Ипак, још један међујезички утицај са Балкана оставио је у њему трага и наставиће то да чини кроз читав средњи век и касније, до наших дана - додир са јужнословенским језицима, чији су се носиоци појавили на историјској сцени на издисају античких цивилизација и убрзо на њиховим развалинама створили своје прве племенске заједнице, а затим и све моћније феудалне државе. И славизми се у албанскоме према фонетској адаптацији такође могу разврстати на старије (крајем праалбанског периода, малобројније) и млађе (бројније, из историјског периода), нешто теже и по критерију исходишног језика на оне из западних јужнословенских (тј. српскохрватског) и оне из источнојужнословенских (македонских или бугарских) говора (тако, рецимо, opangë 'опанак' се сматра за зјсл., према сх. опанак, а оpingë 
за ијсл. облик, уп. мак. опинок, мада ни у самом албанском нису непознате такве фонетске варијације, уп. исто opengë). Исто тако, разликују се општеалбански славизми, који су познати свим говорима албанског језика, и покрајински или локални славизми, много бројнији, за које знају само неки албански дијалекти или говори, најчешће они у интензивном контакту са суседним јужнословенским (македонским и српскохрватским) говорима.

У сваком случају, албанска говорна заједница је деловима или у целини већи део средњег века провела у оквиру неке од словенских државотворних формација, као што су Бугарско царство, Дукља на северу и држава Немањића (нарочито Душаново царство, са чијим су ширењем на југ и албанофоне исељеничке заједнице доспеле у Грчку), а на северу је све до наших времена опстајао снажан албанскојужнословенски билингвизам, што није неважно и за адаптацију нових слојева југославизама у албанском. Међу њима су и бројни топоними словенског порекла широм Албаније, попут Berat < Белград, Korçё < Горица од већих, и др. (в. Селищев 1931; Станишић 1995 с литературом).

Овде ћемо поменути само општеалбанске славизме. Значајан део овог лексичког слоја тиче се феудалног друштвеног и привредног уређења из кога и потиче; тако кућа и покућство: oborr 'двориште', strehë 'стреха', prag 'праг', укључујући алате попут кус 'кључ' (углавном тоск.), patkue patkua 'потковица' (са алб. адаптацијом ova > ue ua) или оружје као pushkë 'пушка', затим grusht 'песница', установе као zakon 'обичаj', bujar 'племенит', gjobë 'глоба' (од стар. gl > gj), krahinë 'покрајина' (с антихијатским h), plaçkё 'пљачка', rob 'роб', krajl 'краљ' (фолк., об. у епици) и апстрактум пеvoјё 'потреба', rend 'ред' (рефлекс сл. назала сведочи о раном узајмљењу), bisedoj 'разговарати', животиње и биљке sokol 'соко', lis 'храст' (уп. лес, алб. „икавски“ рефлекс одражава зјсл. затворено јат пре његове замене), те географске називе попут breg 'обала', jug 'jyг', lëndinë 'ледина' (с рефл. предњег назала пре замене) и др. (За преглед, поред цит. литературе, уп. и Bello \& Krijezi 2016 с тамо нав. библиографијом; Demiraj, op. cit.: 118-123.)

Словенски глаголи су већином морфолошки адаптирани алб. парадигмом II гл. врсте с консонантском алтернацијом $t: s$ (као grabis 'ухватити, заробити', godis 'уредити, наместити, погодити', 
porosis 'поручити', с претпостављеном раном заменом сл. $\check{c}>$ алб. $s$ у време првих контаката, док млађи славизми чувају $\subsetneq$ јер се и оно у међувремену јавило у гласовном систему албанскога, ако није реч једноставно о асимилацији $c ̧-s>s-s$, и др.), дакле адаптирали су се у алб. према облику сл. инфинитива. Такође, занимљив фонетски славизам представља и један од албанских регионалних етнонима lab на југу Албаније, са метатезом ликвиде по јсл. моделу; а поред лексичких основа, албански је опет зајмио и многе словенске везане морфеме.

У славизмима се, међутим, у правилу не јавља карактеристичан алб. дијалекатски ротацизам (уп. zakon), што сведочи о томе да је ова тоск. промена већ била завршена у доба контаката са Словенима, који падају у VI-VII век, те да се дијалекатско раслојавање албанскога на два велика наречја - северно и јужно - у главним цртама већ догодило пре тог периода. И уопште, будући да су највеће гласовне промене, које су деловале на слоју латинизама и на наслеђене алб. основе и супстратску лексику, мењајући их каткада и до непрепознатљивости, већ биле завршене, славизми су у албанскоме, као млађи лексички слој, скоро минимално гласовно измењени и врло лако распознатљиви у етимолошком погледу већ својом спољашњом формом. Управо, и сама природа лексичких контаката између албанског и других језика на Балкану сада је била унеколико другачија - старији су лексички слојеви у процесу формирања албанског језика играли улогу супстрата, коју махом имају и у другим балканским језицима, док су млађи - адстрати или суперстрати, међусобне позајмљенице из сада већ формираних балканских језика или пак речи узете из социолингвистички престижних идиома какви су то били словенски (језик државе) и донекле грчки (језик цркве) у средњем веку те нарочито турски у османско доба.

\section{8. Раносредњовековни одн. касноантички германизми}

Малобројан слој позајмљене лексике из средњег века чине и германизми готског порекла, које је у албанском први идентификовао Јокл (1929). Реч је о остацима проласка источногерманских племена Визигота, Скира и Острогота Балканом током IV и V века. Такве 
готске позајмљенице су shkumё 'пена', tufë 'гомила, група, стадо (о животињама), бокор (о биљу)' и tirk, мн. tirq 'традиционалне мушке уске чакшире од белог платна', те могуће zverk 'врат (са задње стране тела), полеђина, грбина' (Huld 1994), мада постоје и другачије етимологизације.

\section{9. Турцизми}

Готово сви албански турцизми познати су и другим балканским језицима, као и обратно. За све балканске језике, турцизми представљају заједнички суперстрат и тако важан елемент управо општебалканског лексикона. Као и славизми, и турцизми су лако распознатљиви јер су гласовно минимално измењени - у консонантизму, као и у нашем језику, умекшани алофони тур. велара испред предњих вокала рефлектовани су као алб. палатални плозиви или африкате $q, g j$, а у вокализму, адаптација тур. осмочланог сустава је још ближа изворнику него у сх. петочланом систему, јер је албански вокалски систем седмочлан, па тур. ӥ > алб. у, а тур. $1>$ угл. алб. ё (док се оба у сх. угл. рефлектују као у).

Међу турцизмима који су део и савременог албанскога књижевног језика налазе се baba 'отац' (у мн. такође са тур. суфиксом -llarë), кулинарски називи као byrek 'бурек', kafe 'кафа', raki 'ракија', tenxhere 'лонац', tepsi 'тепсија' итд., зграде и покућство као çati 'кров', çorap 'чарапа', dollap 'креденац, орман', dysheme 'под', jastëk 'јастук', kat 'спрат (кат)', tavan 'плафон' (уп. сх. таван, али другог значења), dyqan 'радња (дућан)' и разни занати (суфикси -çi и -xhi за nomina agentis ту настављају тур.) и алати као с̧еkiç 'чекић', бројне друге речи као llafazan 'причалица, хвалисавац', xham 'стакло' (поред латинизма qelq 'id.' < calix), xhami 'џамија' и уопште исламски сакрални називи, xhevahir 'драгуљ', суфикс -llёk (уп. сх. -лук) за колективе и апстрактуме, итд. Наравно, многи од турцизама су крајњег грчког, латинског, персијског, арапског и др. порекла, али су сви у албански, као и у друге балканске језике, доспели османским посредством. (За преглед, в. Demiraj, op. cit.: 123-129; Latifi 2006; inter alia.) 
Као и у другим балканским језицима, током XIX и XX века су пуристичке тежње у албанском књижевном језику највише захватиле овај слој вокабулара. Тако су многи турцизми замењени кованицама од домаћих корена или старим речима, као pёlhurë ум. çarçaf'чаршав, платно', shtrat ум. krevat 'кревет', dritare ум. penxhere 'прозор', fqinj ум. komshi 'сусед (комшија)', syze ум. gjyzlykё 'наочари', orë ум. sahat 'сат', dhomë ум. odë 'соба (одаја)', суфикс -as за етнике и ктетике ум. -li (prishtinas ум. prishtinali и сл.), али и ови други и даље преживљавају као истозначнице, како у књижевном и општем, тако свакако и у разговорном језику или у дијалектима (нарочито на северу), па је пуризам у албанском заправо ретко када успео да турску реч истисне књишком алтернативом, већ је у ствари само створио бројне парове синонима у језику, какви су сви овде наведени.

Једна дијалекатска разлика између севера (гег.) и југа (тоск.) тиче се прозодијске адаптације турцизама са наглашеном ултимом типа babá, kafé (одр. вид kafeja, као rrufé : rrufeja 'гром'), tenxheré и др., који у тоск. дијалекту, као и у стандардном језику, чувају акценат на ултими, док у гег. превлаче акценат на претходни слог-bábë, káfe (одр. вид káfja, као lúle : lulja 'цвет'), tenxhére итд. (за шири ареални контекст, в. и Božović 2016).

\section{0. Млађи грецизми и романизми}

И након периода антике, нове речи из грчкога и романских језика наставиле су да улазе у албански. Нешто су бројније на југу албанске језичке области, и дакако, нарочито су бројне у исељеничким албанофоним енклавама у Грчкој и Италији, које тамо постоје од средњег века, но нису нимало непознате ни општем вокабулару албанскога. Такве су речи livadh 'ливада' (из грч.), adhuroj 'обожавати', barkë 'брод', kamerier 'конобар' итд., углавном познате и другим балканским језицима или одређеним њиховим дијалектима, тако да би се и за њих донекле могло рећи да представљају општебалкански адстратски лексички слој (за преглед, в. Demiraj, op. cit.: 116-118). 


\section{1. Интернационализми}

О интернационализмима кратко говори и Демирај (op. cit.: 129) у своме прегледу лексичких контаката праалбанског и албанскога, али не издваја нарочите примере мимо заиста интернационалних, књишких и научних терминема какве су називи дисциплина, неокласични префиксоиди и суфиксоиди, спортски термини и сл. Оно што је, међутим, особина савременог албанскога - књижевног као и говорног језика - јесте непромењена лакоћа интеграције најразличитијих речи из савремених језика једнако као што је то био случај и у прошлости. Такве, најновије позајмљенице зовемо интернационализмима јер долазе из различитих језика света (угл. западноевропских), са којима сада, за разлику од стања у прошлости, не мора нужно постојати и физички контакт, а реч није искључиво о терминологији, већ и о таквим општим речима као abonoj 'претплатити ce', admirues 'обожавалац', afirmoj 'потврдити', aktual 'тренутни', alarmohem 'узбунити се', dedikoj 'посветити', devijim 'одступање (девијација) ', devotshëm 'посвећен', diskutim 'расправа', ekzistoj 'постојати', favorshëm 'омиљен', interesuar 'заокупљен, заинтригиран', justifikoj 'оправдати', momentalisht 'тренутно' (поред aktualisht), prezantoj 'представити', propozoj 'предложити', supozim 'претпоставка' итд. Иако постоје и домаће истозначнице, оне су често књишке алтернативе интернационализмима, који су сви у потпуности адаптирани у морфолошки систем, као што се види и из наведених облика са домаћим наставцима, сви поседују разгранате породице речи (глагол са одговарајућим глаголским именицама, придевима и прилозима, од којих смо овде навели само по једног представника у сваком примеру) и сви функционишу као одомаћене речи упркос скором датуму уласка у језик, а опет, слично вреди и за друге балканске језике.

Интернационализми, као што је приказано, углавном се адаптирају у породицама глаголских основа I врсте на -ој (тј. назалних основа), које су и иначе најпродуктивнија парадигма у албанском, па тако имају и пуну парадигму актива и медиопасива на -(h)em, глаголске именице на -im, -еsё итд., партицип на -uar, nomen agentis на -ues и др., односно у породицама придева и прилога на -shëm, -isht 
и сл. Поред њих, ту су и нарочито бројне именице на -ion (presion 'притисак' и сл.), -itet (unitet 'јединство' и сл.), итд. Опет, као и код свих других слојева вокабулара о којима је било речи у прошлости албанскога, осим лексичких основа, и овде су спорадично узајмљене и поједине везане морфеме, тако да рестрикција у погледу тога што се све може позајмити и адаптирати у језик нема.

\section{2. Лексичка адаптабилност као обележје балканског језичког савеза}

Моја теза је да је управо ова лакоћа адаптације речи из других језика структурно обележје балканских језика какво је једнако карактерисало њихов лексички систем и у прошлости као и данас, због чега се и данас једнако јављају и релативно брзо интегришу у језички систем бројне позајмљенице из различитих језика. При томе, није неопходно да постоји дословно исти лексички фонд у свим балканским језицима, али постоје, као што смо указали, у највећем броју случајева исти слојеви вокабулара - старобалкански и романски супстрат, затим словенски, млађи грчки и романски адстрати или суперстрат, те балкански турцизми и интернационализми као заједнички лексички суперстрат - само у различитој мери заступљени у појединачним балканским језицима или дијалектима (с највишим степеном, и по Шлајхеру, управо у албанскоме, који је како због географског, тако и због свога социјалног положаја на Балкану, који је и неодвојив од географског, са свима другима био у контакту). Они су последица дуготрајног плурилингвизма, у коме нема речи из једног идиома које би биле непознате говорницима других идиома, и у том смислу су им свима заједничке чак и ако не представљају заједнички лексички фонд, већ остају, макар у почетној фази, социолингвистички маркиране, али то уједно и омогућава многима од њих да пређу ту социолингвистичку баријеру и да се адаптирају у језику као равноправне с домаћим речима. Зато се у балканском лексикону оне и манифестују као лексички слојеви (стратуми), а не као неки конкретан скуп речи које би биле заједничке свим балканским језицима. Тај начин лексичког позајмљивања мо- 
жемо, дакле, сматрати својеврсним страталним позајмљивањем, у коме се читави сегменти вокабулара заједно са културним реалијама које означавају „преливају“ из једног језика у други. При томе није неопходно да те реалије нужно представљају и новину у култури говорне заједнице да би и ознаке за њих биле узајмљене, на чему су неке теорије „речи и ствари“ заснивале своје аргументе (уп. нпр. Вајгандову тезу о поморској терминологији у албанском), већ се оваквим страталним позајмљивањем у језику редовно стварају парови или чак низови синонима, неки од којих временом истискују друге, неки се стилски диференцирају, али многи просто опстају као лексичке могућности, само етимолошки различите, сведочећи о дугом историјском времену међујезичких и културолошких размена и неукротивости језичке материје, која тежњи научника да класификују појаве, утврде границе и изнесу далекосежне закључке о (пра)историји на основу етимологије задаје страшне главобоље.

Те иако су међусобни контакти балканских језика који су то омогућавали донекле прекинути модернизацијом и формирањем националних држава, балкански језици су и данас лексички пропустљиви на исти начин, само окренути ка споља, ка језицима изван Балкана, одакле једнако лако адаптирају бројне интернационализме - речи других језика које нису непознате говорницима балканских језика, чак и ако су у почетку обележене, те које управо зато успевају и да евентуално пређу социолингвистичку баријеру и да их балкански језици у потпуности посвоје. Реч је, дакле, о још једном дубинском феномену дугога трајања у језику, чије дејство још увек није прекинуто упркос променама које се у новијој историји одвијају на његовој површини.

Стога се лексичка адаптабилност може сматрати структурним обележјем које је заједничко свим језицима балканскога ареала. Да је то тако, потврђују и суседни језици који излазе изван овог ареала нпр. мађарски или словеначки на северозападу - у којима стратално позајмљивање није заступљено у тој мери. Овај ефекат балканизације види се и на терену самог српскохрватскога, где је запад мање лексички пропустљив него исток, па га ова изоглоса јасно географски предваја на небалканизовану западну варијанту, где се лексика радије богати творбом или калкирањем него позајмљивањем, и источну, која се одликује вишим степеном лексичке адаптабилности. Речима П. Ивића: 
Лексика се богати творбом нових речи, махом од домаћих, словенских корена, развијањем нових нијанси значења постојећих лексема, али и широким прихватањем позајмљеница. Оријентација српског књижевног језика претежно је космополитска, као на пример руског и пољског или енглеског, а за разлику од неких других словенских и несловенских језика, у којима преовлађују пуристичка настојања. И главна разлика између српске и хрватске варијанте књижевног језика тиче се веће спремности Срба да прихвате страну реч, насупрот склоности Хрвата да је преведу кованицом. (Ивић 1996: 50 et seq.)

Иовадобропознатаособинасрпскохрватскогадобијаобјашњење када се сагледа у ареалнолингвистичкој и културноисторијској - балканистичкој перспективи, једнако као што лексички пуризам и калкирање на северозападу одавде представљају ареално и културноисторијско обележје средњоевропских књижевних језика. По томе се и степен балканизације у језику сразмерно може мерити његовом адаптабилношћу лексикона, те се тако и северозападна граница балканскога језичког савеза, иначе тешко ухватљива и дифузна, јасно открива на терену српскохрватскога све тамо докле год се туђице у њему лакше интегришу у лексички систем него што се замењују преведеницом или кованицом од домаћих корена.

\section{Извори и литература}

Асенова, Петя. Балканско езикознание. Велико Търново: Фабер, 2002. Штампано.

Bello, Dhimitri, и Merima Krijezi. „Славизми у албанском језику и њихов актуелни статус“. Радмила Жугић (ур.). Дијалекти српског језика. Лесковац - Врање: Лесковачки културни центар - Универзитет у Нишу, Педагошки факултет у Врању, 2016. 465-471. Штампано.

Божовић, Ђорђе. „Етимолошки речници албанскога језика“. Прилози проучавању језика 46 (2015): 3-16. Штампано.

Ивић, Павле. „Књижевни језик као инструмент културе и продукт историје народа“. Павле Ивић, и др. (ур.). Историја српске културе. Горњи Милановац Београд: Дечје новине - Удружење издавача и књижара Југославије, 1996. 41-51. Штампано.

Лома, Александар. „Словени и Албанци до XII века у светлу топономастике“. Јован Бојовић (ур.). Становништво словенског поријекла у Албанији. Титоград: Историјски институт СР Црне Горе, 1991. 279-327. Штампано. 
Попов, Бојан. „Положај српскохрватског језика у балканском језичком савезу“. Јужнословенски филолог 40 (1984): 21-43. Штампано.

Селищев, Афанасий. Славянское население в Албании. София: Издание Македонского Научного Института, 1931. Штампано.

Станишић, Вања. Српско-албански језички односи. Београд: Балканолошки институт САНУ, 1995. Штампано.

Božović, Đorđe. „Artikulacione baze u kontaktu: sociofonološki aspekti“. Anali Filološkog fakulteta 28.1 (2016): 305-326. Štampano.

Cimochowski, Wacław. „Des recherches sur la toponomastique de l'Albanie“. Lingua Posnaniensis 8 (1960): 133-145. Print.

Çabej, Eqrem. „Disa mendime mbi marrëdhëniet gjuhësore rumune-shqiptare“. Studime gjuhësore IV. Prishtinë: Rilindja, 1987a. 241-254. Print.

Çabej, Eqrem. „Problemi i autoktonisë së shqiptarëvet në dritën e emravet të vendeve“. Studime gjuhësore IV. Prishtinë: Rilindja, 1987b. 143-154. Print.

Çabej, Eqrem. „Karakteristikat e huazimeve latine të gjuhës shqipe“. Studime gjuhësore IV. Prishtinë: Rilindja, 1987c. 255-289. Print.

Demiraj, Bardhyl. Albanische Etymologien. Amsterdam: Rodopi, 1997. Print.

Demiraj, Shaban. Gjuha shqipe dhe historia e saj. Prishtinë: Rilindja, 1989. Print.

Demiraj, Shaban. Gjuhësi ballkanike. Skopje: Logos-A, 1994. Print.

Friedman, Victor. „The Balkan Languages and Balkan Linguistics“. Annual Review of Anthropology 40 (2011): 275-291. Print.

Huld, Martin. „Accentual Stratification of Ancient Greek Loanwords in Albanian“. Zeitschrift für vergleichende Sprachforschung 99.2 (1986): 245-253. Print.

Huld, Martin. „Albanian zverk - Gothic *swairhs". Historische Sprachforschung / Historical Linguistics 107.1 (1994): 165-171. Print.

Ismajli, Rexhep. „Shqipja dhe rumanishtja“. Rexhep Ismajli (red.). Shqipja dhe gjuhët $e$ Ballkanit. Prishtinë: Akademia e Shkencave dhe e Arteve e Kosovës - Akademia e Shkencave e Shqipërisë, 2012. 185-215. Print.

Jokl, Norbert. „Balkangermanisches im Albanesischen“. Richard Meister (ed.). Festschrift der 57. Versammlung deutscher Philologen und Schulmänner in Salzburg vom 25. bis 29. Sept. 1929. Baden bei Wien: R. M. Rohrer, 1929. 105-137. Print.

Kopitar, Jernej. „Albanische, walachische und bulgarische sprache“. Jahrbücher der Literatur 46 (1829): 59-106. Print.

Latifi, Lindita. Mbi huazimet turke në gjuhën shqipe krahasuar me gjuhët e tjera të Ballkanit. Tiranë: Dudaj, 2006. Print.

Matras, Yaron. Language Contact. Cambridge: Cambridge University Press, 2009. Print.

Miklosich, Franz. Die slavischen Elemente im Rumunischen. Wien: Kaiserliche Akademie der Wissenschaften, 1861. Print.

Miklosich, Franz. Die Fremdwörtern in den slavischen Sprachen. Wien: Kaiserliche Akademie der Wissenschaften, 1867. Print. 
Miklosich, Franz. Die slavischen Elemente im Albanischen mit einer Einleitung... (Albanische Forschungen I). Wien: Kaiserliche Akademie der Wissenschaften, 1870. Print.

Miklosich, Franz. Die romanischen Elemente im Albanischen (Albanische Forschungen II). Wien: Kaiserliche Akademie der Wissenschaften, 1871. Print.

Miklosich, Franz. Die türkischen Elemente in den südost- und osteuropäischen Sprachen. Wien: Kaiserliche Akademie der Wissenschaften, 1884. Print.

Orel, Vladimir. Albanian Etymological Dictionary. Leiden - Boston - Köln: Brill, 1998. Print.

Orel, Vladimir. A Concise Historical Grammar of the Albanian Language. Leiden - Boston - Köln: Brill, 2000. Print.

Sandfeld, Kristian. Linguistique balkanique. Paris: C. Klincksieck, 1930. Print.

Schleicher, August. Die Sprachen Europas... Bonn: H. B. König, 1850. Print.

Skok, Petar. „Slave et albanais“. Arhiv za arbanasku starinu, jezik i etnologiju 2 (1924): 107-126. Štampano.

\section{Đorđe Božović}

University of Belgrade

Faculty of Philology

\section{WAYS OF WORDS IN THE ALBANIAN LANGUAGE}

\section{Summary}

The Albanian language is almost unique among the languages of Europe and the Balkans by the degree of language contact during its entire history since the earliest times, and the diversity of vocabulary strata that it encompasses. This paper presents a periodization of lexical borrowings in Albanian according to their etymology, with a special emphasis on the most recent loans and the so-called internationalisms, as well as the ease of their integration into the lexical system, which reflects the continuity of linguistic and cultural contacts in this speech community. At the same time, it is argued that lexical adaptability represents an areal feature of the Balkan Sprachbund.

Key words: lexical borrowings, periodization, language contact, vocabulary strata, lexical adaptability, Albanian language, Balkan Sprachbund. 